\title{
Molecular genetics of breast cancer progression
}

\author{
Sigurdur Ingvarsson*
}

Somatic changes in the genome of breast cancer cells include amplifications, deletions and gene mutations. Several chromosome regions harboring known oncogenes are found amplified in breast tumors. Despite the high number of chromosome regions deleted in breast tumors the functional relationship to known genes at these locations and cancer growth is mainly undiscovered. Mutations in two tumor suppressor genes (TSG) have been described in a subset of breast carcinomas. These TSG are the TP53, encoding the p53 transcription factor, and the $\mathrm{CDH} 1$, encoding the cadherin cell adhesion molecule. Breast tumors of patients with a germ-line mutation in the BRCA1 or BRCA2 gene have an increase of additional genetic defects compared with sporadic breast tumors. This higher frequency of genetic aberrations could pinpoint genes that selectively promote tumor progression in individuals predisposed to breast cancer due to BRCA1 or BRCA2 germ-line mutations. Accumulation of somatic genetic changes during tumor progression may follow a specific and more aggressive pathway of chromosome damage in these individuals. Although the sequence of molecular events in the progression of breast tumor is poorly understood the detected genetic alterations fit the model of multistep carcinogenesis in both sporadic and hereditary breast cancer. This review will focus on the genetic lesions within the breast cancer cell.

Key words: breast cancer / tumor progression / oncogene / tumor suppressor gene / amplification / deletion / mutation / loss of heterozygosity

(C) 1999 Academic Press

\section{Introduction}

A COMPLEX AND HETEROGENEOUS set of genetic alterations is involved in the etiology of breast cancer. ${ }^{1,2}$ It is believed that breast cancer, like most other can-

From the * Department of Pathology, University Hospital of Iceland, Reykjavik, Iceland

(C) 1999 Academic Press

$1044-579 X / 99 / 040277+12 \$ 30.00 / 0$ cers, has its origin in one cell which through a number of different events becomes malignant. Later additional events lead to the development of different clones with different characteristics. Few genes have been found mutated in breast tumors but large numbers of chromosome arms with so far unidentified genes are affected. These aberrations include both DNA amplifications and deletions (Table 1). The detected genetic abnormalities in breast tumors are amplification of oncogenes $(M Y C, E R B B 2$ and CCND1), mutation of the TSGs TP53 and CDH1 and loss of heterozygosity (LOH) at chromosomes $1,3 p$, $6 \mathrm{q}, 7 \mathrm{q}, 8 \mathrm{p}, 9 \mathrm{p}, 10 \mathrm{q}, 11,13 \mathrm{q}, 16 \mathrm{q}, 17,18 \mathrm{q}, 22 \mathrm{q}$ and $\mathrm{X}$. The LOH may correspond to losses or inactivation of TSGs. Several genetic defects have been detected in premalignant breast tissues, suggesting that TSGs might have a role in their pathogenesis. The sequential steps of molecular lesions during breast tumor progression are poorly understood.

Detection of chromosome abnormalities in breast tumors is based on several methods, such as; flow cytometry, cytogenetic studies, FISH, LOH (loss of heterozygosity), CGH (comparative genome hybridization). These methods have both advantages and disadvantages. Frequently used markers in $\mathrm{LOH}$ studies can give problems in distinguishing between deletions and amplifications. This is especially difficult if the method is based on PCR, but PCR has other advantages, such as utilization of a small sample, and a huge number of highly polymorphic markers tightly distributed over the genome, allowing dense mapping. The CGH and some other methods allow the genome to be screened in a single experiment with respect to losses and gains of genetic material in the tumors, but the resolution power is less than by using molecular markers with well defined locations.

\section{DNA amplification in breast tumors}

Several chromosome regions have been documented to carry a gene amplification in breast tumors. These are chromosome 1q, where no strong gene candidate 
Table 1. Sites of deletions, amplifications and gene mutations in breast neoplasia

\begin{tabular}{|c|c|c|c|c|c|}
\hline $\begin{array}{l}\text { Chromosomal } \\
\text { locations }\end{array}$ & $\begin{array}{c}\text { Deletion / } \\
\text { amplification }\end{array}$ & $\%$ Of tumors & $\begin{array}{l}\text { Mutated/ } \\
\text { amplified gene }\end{array}$ & $\begin{array}{l}\text { Possible } \\
\text { TSG }\end{array}$ & Reference \\
\hline $1 p$ & Deletion & $36-54 \%$ & & & $3-7$ \\
\hline $1 \mathrm{q}$ & Deletion/amplification & $50-67 \%$ & & & $4,6,8$ \\
\hline $3 \mathrm{p}$ & Deletion & $34-45 \%$ & & FHIT & 9,10 \\
\hline $6 q$ & Deletion & $19-62 \%$ & & & $11-15$ \\
\hline $7 q$ & Deletion & $0-84 \%$ & & & $16-19$ \\
\hline $8 \mathrm{p}$ & Deletion & $47-58 \%$ & & & 20,21 \\
\hline $8 q$ & Amplification & $15 \%$ & $\mathrm{MYC}^{*}$ & & 22 \\
\hline $9 p$ & Deletion & $38-58 \%$ & & & 23,24 \\
\hline $10 q$ & Deletion & & & PTEN & 25 \\
\hline $11 q$ & Deletion/amplification & $23-59 \%$ & $\mathrm{CCND}^{*}$ & & $26-31$ \\
\hline $13 q$ & Deletion & $33-75 \%$ & BRCA2+† & BRCA2, RB1 & $32-35$ \\
\hline $16 q$ & Deletion & $57-85 \%$ & $\mathrm{ECDH}+$ & & $36-39$ \\
\hline $17 \mathrm{p}$ & Deletion & $41-73 \%$ & $\mathrm{TP} 53 \dagger$ & & $40-42$ \\
\hline $17 q$ & Deletion/amplification & $30-70 \%$ & $\mathrm{BRCA} 1++/ \mathrm{ERBB} 2 *$ & BRCA1 & 43,44 \\
\hline $18 \mathrm{q}$ & Deletion & $15-65 \%$ & & & $45-48$ \\
\hline $20 q$ & Amplification & $5-26 \%$ & & & $49-52$ \\
\hline $22 q$ & Deletion & $40 \%$ & & & 53 \\
\hline$X^{1}$ & & $48 \%$ & & & 54 \\
\hline
\end{tabular}

*Amplified gene.

$\dagger$ Mutated gene.

¡Germ-line mutations, somatic mutations are rare.

has been detected, chromosome $8 \mathrm{q} 24$, harboring the $M Y C$ oncogene, chromosome $11 \mathrm{q}$, harboring the CCND1 gene, chromosome 17q, harboring the HER2 gene and chromosome $20 \mathrm{q}$, where no strong gene candidate has been detected..$^{8,22,49,50,55-57}$ In general only a subset of invasive breast cancer shows amplification at these regions, ranging from 15 to $20 \%$. Nonetheless, elevated expression of CCND1 and HER2 is detected in primary breast carcinoma, when examined immunohistochemically, in a larger proportion of cases. ${ }^{58-62}$ The myc oncoprotein is a transcriptional regulator and its expression is strongly associated with cell proliferation and cell differentiation. The CCND1 gene encodes the cyclinD1, an important regulatory molecule of the cell cycle. The Her 2 protein is a transmembrane receptor with homology to the epidermal growth factor receptor and contains intrinsic tyrosine kinase activity. Although the biochemical role of these oncoproteins is fairly well characterized, their exact role in breast cancer is poorly defined.

\section{Mutated genes in breast tumors}

\section{Tp53}

The TP53 gene encodes a transcription factor, $p 53$, that binds as a tetramer to a specific DNA sequence.
The spectrum of TP53 mutations detected in breast tumors with respect to epidemiology has recently been reviewed. ${ }^{63}$ This TSG is the most frequently mutated gene in human tumors; approximately $50 \%$ of tumors have a mutation in this gene. In breast cancer this frequency is slightly lower; $15-34 \%$ of tumors have a mutation in the TP53 gene in most ethnic groups, but a higher proportion in certain regions of Japan, or $56-71 \% .{ }^{63}$ The majority of TP53 mutations are missense, in contrast to mutations in several other TSGs, where the majority of mutations result in a truncated protein. Some of the TP53 mutations are dominant negative. The $p 53$ protein is important in the G1 checkpoint of the cell cycle and one described pathway involves the cyclin-dependent kinase inhibitor (CKI) $p 21 .{ }^{64-67}$ Upon DNA damage or other stress environment in the cell, $p 53$ accumulates, transactivates the gene encoding the $p 21$ inhibitory protein, and the cell halts in G1 phase of the cell cycle. P53 can even induce apoptosis, and one known pathway is by transcriptional activation of the gene encoding Baxl, an inducer of apoptosis. ${ }^{68}$ Interaction of $p 53$ with proteins important for DNA repair has been reported, but functional evidence for a role in DNA repair is still lacking. A feasible model is that $p 53$ is important for blocking the cell from entering the S-phase of the cell cycle upon cell damage, and induces apoptosis if the damage is over- 
whelming. By failure of $p 53$ normal function due to mutation there is a risk of accumulation of genomic instability and mutations in additional genes. Germline mutations are found in family members of the $\mathrm{Li}-\mathrm{Fraumeni}$ syndrome, and individuals within these families have inherited elevated risk of several cancer types, including breast cancer. ${ }^{69}$

\section{E-cadherin and lobular breast carcinoma}

The E-cadherin gene, $C D H 1$, has been found mutated in a large portion of lobular breast tumors. ${ }^{70-72}$ The gene is located on chromosome 16q22.1, a region frequently deleted in breast tumors. The $\mathrm{CDH} 1$ behaves like a typical TSG in lobular breast cancer, with one copy of the gene deleted, while the other copy is mutated. No mutations have been detected in the CDH1 gene in tumors in the breast of the ductal histological type. This is the clearest evidence of molecular difference in the two histological types of breast cancer although TP53 mutations are predominantly in tumors of the ductal histological type and other differences are also detected at chromosome level (see later). Reduced expression of E-cadherin has been found in both lobular and ductal breast cancer. $^{73,74}$ Deletions of chromosome $16 q 22.1$ are frequent in ductal carcinoma and this is the highest documented loss of a chromosome region in sporadic breast cancer. ${ }^{38}$ It seems that the $C D H 1$ gene does not behave like a typical TSG in ductal breast cancer with respect to the Knudson's two-hit model. ${ }^{75}$ Two explanations of this difference are possible: (1) either a gene other than $C D H 1$ is the target of the $16 \mathrm{q} 22.1$ deletions in ductal compared to lobular carcinoma of the breast; or (2) the progression of ductal carcinoma is more sensitive to loss of one copy of the $\mathrm{CDH} 1$ gene, and corresponding reduction of expression, than lobular breast cancer, where both copies need to be knocked out for further progression to malignant invasive growth.

The E-cadherin protein is a calcium-dependent cell adhesion molecule, involved in homophilic cell-cell interactions. Loss of function of E-cadherin seems to facilitate malignant invasive growth of breast cancer cells. Other cancer types of epithelial origin, like colon cancer also exhibit reduced expression of $E$ cadherin. Germ-line mutations in the E-cadherin gene are found in hereditary gastric cancer. ${ }^{76}$

\section{The estrogen receptor gene}

Mutations and abnormal transcripts of the estrogen receptor gene ( $E S R)$ have been reported in tumors of the breast (recently reviewed by Murphy et al, 1997 and Dowsett et al, 1997). ${ }^{77,78}$ The majority of the work on variant mRNA has concentrated on their expression in malignant tissues, but it has become apparent that many of them also exist in normal tissues. ${ }^{79,80}$ Several reports are consistent with the involvement of variant ERs in the establishment of certain pathological phenotypes of the breast and it has been suggested that some of the variant ERs have a role in breast tumorigenesis. ${ }^{81-83}$ Still, the physiological and pathological function of variant $E R$ proteins remains unclear. Although it has been suggested that ER mutants may contribute to hormone resistance, direct evidence of an association of $E R$ mutants in breast carcinomas with hormone resistance does not exist. ${ }^{82,83}$ The studies of germ-line mutations of the ESR gene do not support the hypothesis that $E R$ alterations are a major factor in breast cancer risk. ${ }^{84}$ The fundamental question if $E R$ mRNA variants have physiological or pathological significance remains conclusively unanswered. Although point mutations in $E R$ can have profound effects on protein function in model systems, their relevance to breast cancer appears to be slight, in terms of risk of development and phenotype of established tumors.

\section{The PTEN gene}

The PTEN gene encodes a protein tyrosine phosphatase with homology to tensin. Somatic mutations in the PTEN gene are rare in breast tumors. ${ }^{85,86}$ Germ-line mutations in the PTEN gene are responsible for Cowden disease (CD). ${ }^{87}$ Germ-line mutations in the PTEN gene predispose to breast cancer in association with $\mathrm{CD} .{ }^{87}$

\section{BRCA1 and BRCA2 genes}

Mutations in the BRCA1 and BRCA2 genes are rare at somatic level but germ-line mutations in these genes predispose to breast cancer. ${ }^{88-91}$ An elevation of deletions and amplifications at several chromosome arms in tumors of BRCA1 and BRCA2 carriers compared to tumors from individuals without this mutation have been reported.$^{92-95}$ A genome-wide search for the chromosome changes in tumors of BRCA 1 and BRCA2 carriers by $\mathrm{CGH}$ demonstrated a higher frequency of aberrations at several chromosome arms compared to sporadic tumors. ${ }^{93}$ These results suggested a specific tumor progression path- 


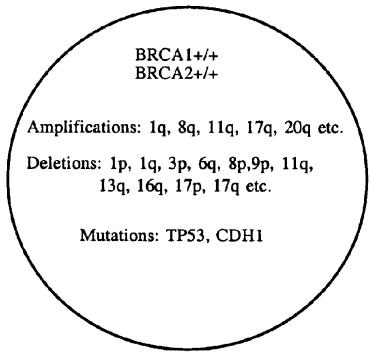

A

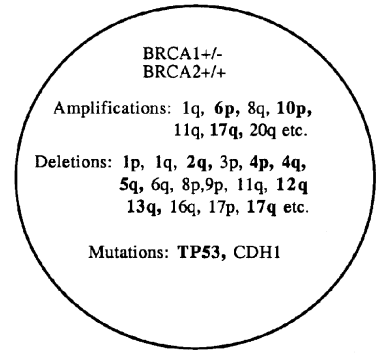

B

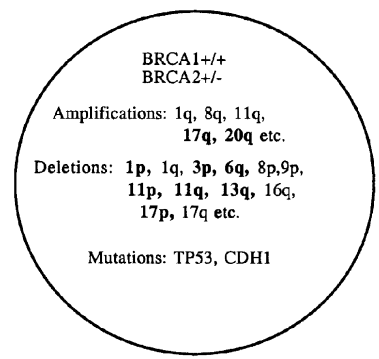

C

Figure 1. Major somatic changes in sporadic tumors (A), tumors from individuals carrying a germ-line mutaion in the BRCA1 gene (B), and tumors from individuals carrying germ-line mutations in the BRCA2 gene (C). Alterations found at higher frequency in BRCA1 or BRCA2 tumors are characterized by bold numbers and letters. This figure is based on results from refs 92-98,104,105,108. The order of chromosome alterations is mostly unknown but some of them have been reported to appear in premalignant tumor growth (see text). In the case of BRCA1 and BRCA2 it is not clear if loss of wild-type $17 q$ and $13 q$, carrying the corresponding genes, respectively, must be prior to enhanced rate of losses and gains at other chromosome regions.

way in patients predisposed to breast cancer due to BRCA1 or BRCA2 mutation. The majority of the regions have previously been implicated in sporadic breast cancer, but in most cases at lower frequency (Figure 1).

Somatic loss of the wild-type chromosome in tumors of BRCA1 and BRCA2 mutation carriers suggest that both alleles of the corresponding gene are inactivated in cancer, a pattern expected of a TSG. ${ }^{96-98}$ Accordingly a high frequency of loss at chromosome $17 \mathrm{q}$ (where the BRCA1 gene is located) is found in tumors of individuals carrying a BRCA 1 germ-line mutation, and a high frequency of loss at chromosome $13 \mathrm{q}$ (where the BRCA2 gene is located) is found in tumors of individuals carrying a BRCA2 germ-line mutation. Earlier findings based on the loss of wild-type chromosome $13 q$ suggested a strong selection of tumor cells with both alleles of the BRCA2 gene being mutated. ${ }^{97,98}$ It has been shown that the loss at $13 q$ involves the BRCA2 gene in the majority of tumors. ${ }^{95}$ So far it is not clear if loss of the wild-type chromosome carrying the BRCA1 or BRCA2 genes, respectively, is prerequisite to enhanced risk of further chromosome alterations.

The $3 p$ chromosome region showing elevation of $3 \mathrm{p} \mathrm{LOH}$ in BRCA2 tumors involves the FHIT gene at 3p21.1-p14.2. ${ }^{94,95}$ Several reports have described abnormalities in the FHIT gene in breast carcinomas. ${ }^{99-101}$ Furthermore, the FHIT gene has been shown to suppress tumorigenicity of cancer cells. ${ }^{102}$ The FHIT gene encompasses the carcinogen sensitive common fragile site, FRA $3 B .{ }^{103}$
Crook et al has documented an elevated proportion of TP53 mutations in tumors from BRCA1 carriers compared to sporadic tumors. ${ }^{104}$ These results suggest that loss of cell cycle checkpoint due to somatic TP53 mutation may increase the rate of BRCA1 tumorigenesis. Furthermore, the region at chromosome $17 \mathrm{p}$ harboring the TP53 gene shows a significant elevation of $\mathrm{LOH}$ in BRCA2 tumors in comparison to sporadic tumors. ${ }^{105}$ Knockout mouse experiments have suggested that $p 53$ protein is accumulating in Brca2 defective mice and that a cell cycle checkpoint mechanism is activated due to defective BRCA2 protein and corresponding DNA damage. ${ }^{106}$ It has been suggested that accumulation of $p 53$ protein can reduce the malignant behavior of BRCA2 defective tumors due to cell cycle checkpoint activation. ${ }^{107}$ Still, no significant elevation of TP53 somatic mutations is detected in tumors from individuals carrying BRCA2 germ line mutation. ${ }^{105,108}$ The growth advantage of BRCA2 defective tumors may be enhanced if only one copy of the TP53 gene is deleted.

The association of both Brca1 and Brca2 proteins with the Rad51 protein establishes a direct link between these proteins and the control of genomic integrity and stability since $\operatorname{Rad} 51$ is required for meiotic and mitotic recombination events and the repair of double stranded DNA breaks. ${ }^{109,110}$ Furthermore, fibroblasts from Brca2 knockout mice show defects in DNA repair of double stranded breaks. ${ }^{107}$ Defects in chromatid exchange during mitotic recombination result in numerous spontaneous chromosomal abnormalities in fibroblasts from Brca2 
knockout mice. ${ }^{111}$ The increased number of somatic alterations at chromosome level may reflect the inability of mutated Brcal or Brca2 proteins to participate in the Rad51 mediated repair. A putative model of $\mathrm{LOH}$ selection might be that due to improper fidelity in mitotic recombination and corresponding DNA repair, the tumors with BRCA1 or BRCA2 mutation follow a more aggressive pathway of chromosome damage than tumors without this mutation. Whether loss of additional genes is involved in the tumor progression of BRCA1 and BRCA2 carriers compared to sporadic tumors remains unsolved.

The architecture of the $\mathrm{LOH}$ is different in BRCA2 and sporadic tumors at some chromosome regions, as the BRCA2 tumors involve larger regions. ${ }^{94,95}$ In tumors showing loss at a given chromosome arm, specific regions can be preferably affected in BRCA1 or $B R C A 2$ tumors in comparison to sporadic tumors. These findings may pinpoint candidate loci for the search of genes that when inactivated promote tumor progression in individuals predisposed to breast cancer due to a germ-line BRCA1 or BRCA2 mutation.

The large number of abnormal chromosomes observed in tumor cells in BRCA1 and BRCA2 individuals supports the belief that their protein product is involved in maintaining appropriate chromosome segregation and/or chromosomal repair. The high number of genetic defects that are detected in BRCAI and $B R C A 2$ carriers indicates that germ-line mutation of these genes results in an accelerated accumulation of secondary somatic genetic changes in the tumors. This acceleration could explain the aggressive phenotype of tumor growth in tumors from $B R C A 2$ carriers, as breast cancers associated with the $B R C A 2$ mutation are high grade tumors with a rapid proliferation rate. ${ }^{112}$ The chromosome defects in BRCA1 and BRCA2 tumors are likely to be helpful in the understanding of the somatic genetic progression pathways that contribute to the development of malignancy in genetically predisposed individuals.

\section{Premalignant breast tissue and tumor progression}

The development of breast cancer involves many types of genes that need to be activated or inactivated in order to promote malignancy. This is a complex process, where for most tumor types the steps involved are not known. For breast cancer the sequential steps in gene alterations with respect to tumor progression are not clear, far less understood than what is currently the best example of tumor progression, colorectal carcinoma. Putative precursor stages to invasive tumor growth; such as usual ductal hyperplasia, atypical hyperplasia and cancer in situ of the breast have been studied. The detected LOH in hyperplastic disease suggests that hyperplasias are really benign neoplasms and inactivation of TSGs participates in their development. ${ }^{113}$ In general the studies on in situ, locally advanced and metastatic tumors indicate a complex pattern of alterations. Most of the genetic defects detected in invasive cancer are also detected in in situ carcinoma. ${ }^{17,20,113-117}$ The large number of alterations that have been identified at the genetic level fit the model of multistep carcinogenesis of breast cancer. No gatekeeper gene has been proposed for breast cancer, in contrast to the $A P C$ gene deactivation in colon cancer.

Gene amplifications appear to be a late event in tumor progression, being mainly found in tumor cells that have acquired genomic instability and tolerate its presence. ${ }^{2}$ None of the oncogenes located at amplified chromosomal region are amplified in benign breast disease..$^{58,118,119}$ In ductal hyperplasia with or without atypia, oncogene amplification is detected at only low levels for genes located on 11 q13. ${ }^{120}$ It may be concluded that oncogene amplification is not an early event in the multistep carcinogenesis of breast cancer but emerges in ductal carcinoma in situ. ${ }^{2}$ The percentage of oncogene amplification varies with the histological subtype of ductal carcinoma in situ, for example, HER2 amplification is lower in the cribriform type compared to the comedo type. ${ }^{121}$ The overall rate of HER2 amplification in ductal carcinoma in situ is decreasing towards the development of invasive ductal carcinoma and is absent in lobular carcinoma in situ and very rare in invasive lobular carcinoma. ${ }^{122}$ This is different for other oncogenes; for example, CCND1 amplification is similar in ductal carcinoma in situ and in invasive ductal carcinoma. ${ }^{120}$ All oncogenes show low amplification rate in invasive lobular carcinoma. ${ }^{121}$ These findings are consistent with the biological and histological difference between lobular and ductal carcinoma in situ. It can be concluded that the oncogene amplification seems to be specific for a certain histological subtype; the oncogene mediated proliferation is predominantly at the intermediate state of breast cancer development and is not of obvious importance in the progression to metastatic disease. ${ }^{2}$

In a study of benign breast disease (fibroadenomas, benign phyllode tumors, fibrocytic diseases) no $\mathrm{LOH}$ was detected at chromosome loci 1p, 3p, 7q, 11p, 
$17 p, 17 q$ and $18 q .{ }^{119}$ O'Connell et al reported that in hyperplasias from noncancerous breast, $\mathrm{LOH}$ at any given locus is rare although $37 \%$ of usual ductal hyperplasia and $42 \%$ of atypical ductal hyperplasias show losses, suggesting that the development of hyperplasias can involve many different TSGs. ${ }^{123}$ Apocrine cysts and papillomas of the breast are negative for $\mathrm{LOH}$, while hyperplasias of usual type exhibit $\mathrm{LOH}$ at chromosome regions $16 \mathrm{q}, 17 \mathrm{p}$ and $17 \mathrm{q}$ and the atypical ductal hyperplasia show LOH at chromosomes $16 q$ and $17 p{ }^{124,125}$ In ductal carcinoma in situ from non-cancerous breasts, $\mathrm{LOH}$ was common, including $\mathrm{LOH}$ at loci on chromosome $16 \mathrm{q}, 17 \mathrm{p}$ and $17 q$, suggesting that inactivation of TSGs in these regions may be important in the development of non-invasive breast cancer. ${ }^{123}$ Additional $\mathrm{LOH}$ was detected in in situ growth in cancerous breasts, for instance on chromosome $2 p, 11 p$ and $17 q$, suggesting that genetic alterations in these regions may be important in the progression to invasive disease. ${ }^{123}$ Certain changes appear to develop early, e.g. loss at chromosome 3p, while other changes, like loss at chromosome 11p and 15, appear late in tumor progression. ${ }^{126-128}$ In a subset of tumors, loss of $11 p$ was only observed in the invasive tumor and not the corresponding cancer in situ. ${ }^{125}$ High incidence of loss on chromosome 15 was detected in metastasis from the breast, suggesting that a gene on chromosome 15 contributes to the pathogenesis of metastatic breast carcinoma. ${ }^{128}$ In general, these findings support the idea that the putative precursors and the cancers are related. Some of the changes found in the hyperplastic, premalignant and malignant breast epithelium, like LOH of 3p, also exist in apparently normal cells adjacent to the tumor. ${ }^{126} \mathrm{~A}$ model to explain this is that the first mutation may occur early in breast cancer progression before clonal expansion occurs, suggesting that the molecular heterogeneity of the invasive tumor may occur at the earliest detectable stages of progression.

\section{RER and breast cancer}

Replication errors (RER) are key features of hereditary non-polyposis colorectal cancer (HNPCC) and an indicator of defects in the DNA mismatch repair genes. ${ }^{129}$ Screening of sporadic colorectal tumors has revealed that $12-28 \%$ of cases are of the $\mathrm{RER}^{+}$ phenotype. ${ }^{130,131}$ It has been reported that $\mathrm{RER}^{+}$is also present in significant sub-sets of common, nonhereditary forms of cancer of the gastrointestinal tract, endometrium and lung and, at a lower frequency, in ovarian, brain and soft-tissue tumors. ${ }^{132-136}$ Breast cancer is rarely associated with the HNPCC phenotype. ${ }^{137}$ Still, Glebov et al reported a high frequency of RER ${ }^{+}$in breast cancers from individuals with a positive family history of the disease. ${ }^{133} \mathrm{In}$ their series, RER $^{+}$was seen in five of $14(35 \%)$ cases of sporadic breast tumors and 15 of $18(83 \%)$ in the familial tumors. A study performed on 23 invasive lobular breast carcinomas reported $\mathrm{RER}^{+}$in nine cases (39\%). ${ }^{138}$ Another study revealed $\mathrm{RER}^{+}$at a single locus on chromosome $11 \mathrm{p} 15.5$ in 20 of 69 (29\%) primary breast tumors analyzed. ${ }^{139}$ These results are inconsistent with the findings of Peltomaki $e t$ al who found no $\mathrm{RER}^{+}$phenotypes in 86 breast tumors examined. ${ }^{132}$ In independent studies RER ${ }^{+}$ has been reported in 5\% (5/93) and 8\% (8/100) of primary breast tumors, respectively. ${ }^{140,141}$ Our results indicate that RER exists in $8 / 419(1.9 \%)$ of primary ductal breast cancer cases at one or more chromosomal loci and that no RER was observed in 40 cases of primary lobular breast cancer. ${ }^{142}$ Bergthorsson et al suggested three explanations for the appearance of replication error in sporadic breast cancer: ${ }^{143}$ First, the instability observed is not caused by mismatch repair gene defects, but rather reflects the ability of this repair system to work in the environment provided by the tumor cell. Secondly, sporadic RER ${ }^{+}$ tumors could be caused by mild mutations, and perhaps in different genes. Finally, sporadic breast tumors may have a defective mismatch repair system but need an additional environmental or genetic co-factor to result in a strong $\mathrm{RER}^{+}$phenotype. The breast cancer cases with RER do not seem to be part of a HNPCC syndrome since a family history of colorectal cancer growth is not detected in relatives. ${ }^{142}$ It can be concluded that RER is a rare somatic event during human breast carcinogenesis and may be associated with progression of breast carcinomas.

\section{Mutations and prognosis}

A large number of molecular markers have been suggested to give prognostic information in breast cancer. Overexpression and/or amplification of the HER2 oncogene generally correlates with poor prognosis for breast cancer patients. ${ }^{59,61,144,145}$ The HER2 overexpression correlates with tumor grade, size, relapse rate, and lymph node and distant metastases. ${ }^{59}$ In addition to prognosis and prediction of response 
to chemotherapeutic drugs, the HER2 oncogene may also have an important role in breast cancer therapy. ${ }^{62}$ Baselga et al used weekly intravenous injections of humanized monoclonal antibody against the Her 2 protein in patients with overexpressing metastatic breast cancer in phase II clinical trial. Their results were not dramatic, but $11.6 \%$ overall response rate in this usually refractory subset of patients was documented. ${ }^{62}$

Other molecular markers have been studied less with respect to prognosis and therapy. It has been suggested that $p 53$ mutation is an important prognostic indicator of short-term survival for breast cancer patients. ${ }^{146,147}$ The TP53 gene mutations could be an important factor to identify node-negative patients who have a poor prognosis in the absence of adjuvant therapy. ${ }^{147}$ Furthermore, LOH at chromosomes $1 \mathrm{p}$, $3 p, 6 q, 11 q$ and $13 q$ have been shown to be of independent prognostic value. , $8,10,12,27,31,35,148$ It is not clear if this prognostic association is due to inactivation of specific TSGs or reflects the general chromosome instability in the tumor. E-cadherin expression has been shown to be associated with decreased overall survival of breast cancer patients. ${ }^{149,150}$

\section{Conclusions}

Despite intense efforts the question remains unanswered what gene losses are involved in the pathogenesis of breast cancer located at the numerous chromosome arms altered in breast tumors. There can be little doubt that several genes from these chromosome regions are of importance, so far not characterized with respect to breast cancer pathogenesis. Although molecular function of the $p 53$ protein is well documented, mutations in the TP53 gene are only involved in a subset of breast tumors. The $E$ cadherin gene is mutated in a smaller portion of breast tumors, and only in tumors of the lobular histological type. Breast tumors bear all the hallmarks of multiple gene alterations, where sequence of events is poorly understood. At present it is not possible to establish a complete model of multistep carcinogenesis in the breast. The somatic chromosome alterations are more frequent in tumors from individuals carrying BRCA1 and BRCA2 germ-line mutations than in sporadic tumors, possibly reflecting the putative role of their protein products in DNA recombination and repair. Further studies will doubtless elucidate new genes of interest in normal and transformed cells of the breast epithelium and reveal the function of their protein products in normal and malignant growth.

\section{References}

1. Kerangueven F, Noguchi T, Coulier F, Allione F, Wargniez V, Simony-Lafontaine J, Longy M, Jacquemier J, Sobol H, Eisinger F, Birnbaum D (1997) Genome-wide search for loss of heterozygosity shows extensive genetic diversity of human breast carcinomas. Cancer Res 57:5469-5474

2. Beckmann MW, Niederacher D, Schnurch HG, Gusterson BA, Bender HG (1997) Multistep carcinogenesis of breast cancer and tumour heterogeneity. J Mol Med 75:429-439

3. Bieche I (1994) Champeme MH. Lidereau R. A tumor suppressor gene on chromosome 1p32-pter controls the amplification of MYC family genes in breast cancer. Cancer Res 54:4274-4276

4. Hoggard N, Brintnell B, Howell A, Weissenbach J, Varley J (1995) Allelic imbalance on chromosome 1 in human breast cancer. II. Microsatellite repeat analysis. Genes Chromosomes Cancer 12:24-31

5. Nagai H, Negrini M, Carter SL, Gillum DR, Rosenberg AL, Schwartz GF, Croce CM (1995) Detection and cloning of a common region of loss of heterozygosity at chromosome $1 \mathrm{p}$ in breast cancer. Cancer Res 55:1752-1757

6. Loupart ML, Armour J, Walker R, Adams S, Brammar W, Varley J (1995) Allelic imbalance on chromosome 1 in human breast cancer. I. Minisatellite and RFLP analysis. Genes Chromosomes Cancer 12:16-23

7. Ragnarsson G, Sigurdsson A, Eiriksdottir G, Barkardottir RB, Jonasson JG, Ingvarsson S (1996) Loss of heterozygosity at chromosome $1 \mathrm{p}$ in human breast cancer: association with high S-phase, reduced patient survival and deletions at other chromosome regions. Int J Oncol 9:731-736

8. Borg A, Zhang QX, Olsson H, Wenngren E (1992) Chromosome 1 alterations in breast cancer: allelic loss on $1 p$ and $1 q$ is related to lymphogenic metastases and poor prognosis. Genes Chromosomes Cancer 5:311-320

9. Chen LC, Matsumura K, Deng G, Kurisu W, Ljung BM, Lerman MI, Waldman FM, Smith HS (1994) Deletion of two separate regions on chromosome $3 p$ in breast cancers. Cancer Res 54:3021-3024

10. Eiriksdottir G, Bergthorsson JT, Sigurdsson H, Gudmundsson J, Skirnisdottir S, Egilsson V, Barkardottir RB, Ingvarsson S (1995) Mapping of chromosome 3 alterations in human breast cancer using microsatellite PCR markers: correlation with clinical variables. Int J Oncol 6:369-375

11. Devilee P, van Vliet M, van Sloun P, Kuipers Dijkshoorn N, Hermans J, Pearson PL, Cornelisse CJ (1991) Allelotype of human breast carcinoma: a second major site for loss of heterozygosity is on chromosome 6q. Oncogene 6:1705-1711

12. Bragadottir G, Eiriksdottir G, Sigurdsson A, Barkardottir RB, Gudmundsson J, Jonasson JG, Ingvarsson S (1995) Loss of heterozygosity at chromosome $6 \mathrm{q}$ correlates with tumor progression and patient survival. Int J Oncol 871-876

13. Orphanos V, McGown G, Hey Y, Boyle JM, Santibanez-Koref M (1995) Proximal 6q, a region showing allele loss in primary breast cancer. Br J Cancer 71:290-293

14. Iwase H, Greenman JM, Barnes DM, Bobrow L, Hodgson S, Mathew CG (1995) Loss of heterozygosity of the oestrogen receptor gene in breast cancer. Br J Cancer 71:448-450

15. Sheng ZM, Marchetti A, Buttitta F, Champeme MH, Campani D, Bistocchi M, Lidereau R, Callahan R (1996) Multiple regions of chromosome $6 \mathrm{q}$ affected by loss of heterozygosity in primary human breast carcinomas. $\mathrm{Br} \mathrm{J}$ Cancer 73:144-147 
16. Bieche I, Champeme MH, Matifas F, Hacene K, Callahan R, Lidereau R (1992) Loss of heterozygosity on chromosome 7q and aggressive primary breast cancer. Lancet 339:139-143

17. Champeme MH, Bieche I, Beuzelin M, Lidereau R (1995) Loss of heterozygosity on 7q31 occurs early during breast tumorigenesis. Genes Chromosomes Cancer 12:304-306

18. Zenklusen JC, Bieche I, Lidereau R, Conti CJ (1994) (C-A)n microsatellite repeat D7S522 is the most commonly deleted region in human primary breast cancer. Proc Natl Acad Sci USA 91:12155-12158

19. Kristjansson AK, Eiriksdottir G, Ragnarsson G, Sigurdsson A, Gudmundsson J, Barkardottir RB, Jonasson JG, Egilsson V, Ingvarsson S (1997) Loss of heterozygosity at chromosome $7 \mathrm{q}$ in human breast cancer: association with clinical variables. Anticancer Res 17:93-98

20. Yaremko ML, Recant WM, Westbrook CA (1995) Loss of heterozygosity from the short arm of chromosome 8 is an early event in breast cancers. Genes Chromosomes Cancer 13:186-191

21. Yaremko ML, Kutza C, Lyzak J, Mick R, Recant WM, Westbrook CA (1996) Loss of heterozygosity from the short arm of chromosome 8 is associated with invasive behavior in breast cancer. Genes Chromosomes Cancer 16:189-195

22. Kreipe H, Feist H, Fischer L, Felgner J, Heidorn K, Mettler L (1993) Parwaresch R. Amplification of c-myc but not of c-erbB-2 is associated with high proliferative capacity in breast cancer. Cancer Res 53:1956-1961

23. Eiriksdottir G, Sigurdsson A, Jonasson JG, Agnarsson BA, Sigurdsson A, Gudmundsson J, Bergthorsson JT, Barkardottir RB, Egilsson V, Ingvarsson S (1995) Loss of heterozygosity on chromosome 9 in human breast cancer: association with clinical variables and genetic changes at other chromosome regions. Int J Cancer 64:378-382

24. Brenner AJ, Aldaz CM (1995) Chromosome 9p allelic loss and p16/CDKN2 in breast cancer and evidence of p16 inactivation in immortal breast epithelial cells. Cancer Res 55:2892-2895

25. Singh B, Ittmann MM, Krolewski JJ (1998) Sporadic breast cancers exhibit loss of heterozygosity on chromosome segment 10q23 close to the Cowden-disease locus. Genes Chromosomes Cancer 21:166-171

26. Champeme MH, Bieche I, Lizard S, Lidereau R (1995) 11 q13 amplification in local recurrence of human primary breast cancer. Genes Chromosomes Cancer 12:128-133

27. Schuuring E, Verhoeven E, van Tinteren H, Peterse JL, Nunnink B, Thunnissen FB, Devilee P, Cornelisse CJ, van de Vijver MJ, Mooi WJ et al (1992) Amplification of genes within the chromosome 11q13 region is indicative of poor prognosis in patients with operable breast cancer. Cancer Res 52:5229-5234

28. Hampton GM, Mannermaa A, Winquist R, Alavaikko M, Blanco G, Taskinen PJ, Kiviniemi H, Newsham I, Cavenee WK, Evans GA (1994) Loss of heterozygosity in sporadic human breast carcinoma: a common region between 11q22 and 11q23.3. Cancer Res 54:4586-4589

29. Carter SL, Negrini M, Baffa R, Gillum DR, Rosenberg AL, Schwartz GF, Croce CM (1994) Loss of heterozygosity at 11q22-q23 in breast cancer. Cancer Res 54:6270-6274

30. Gudmundsson J, Barkardottir RB, Eiriksdottir G, Arason A, Egilsson V, Ingvarsson S (1995) Loss of heterozygosity at chromosome 11 in breast cancer: association of prognostic factors with genetic alterations. Br J Cancer 72:696-701

31. Winquist R, Hampton GM, Mannermaa A, Blanco G, Alavaikko M, Kiviniemi H, Taskinen PJ, Evans GA, Wright FA, Newsham I et al (1995) Loss of heterozygosity for chromosome 11 in primary human breast tumors is associated with poor survival after metastasis. Cancer Res 55:2660-2604

32. Cleton-Jansen AM, Collins N, Lakhani SR, Weissenbach J, Devilee P, Cornelisse CJ, Stratton MR (1995) Loss of het- erozygosity in sporadic breast tumours at the BRCA2 locus on chromosome 13q12-q13. Br J Cancer 72:1241-1244

33. Kerangueven F, Allione F, Noguchi T, Adelaide J, Sobol H, Jacquemier J, Birnbaum D (1995) Patterns of loss of heterozygosity at loci from chromosome arm $13 q$ suggests a possible involvement of BRCA2 in sporadic breast tumors. Genes Chromosomes Cancer 13:291-294

34. Hamann U, Herbold C, Costa S, Solomayer EF, Kaufmann M, Bastert G, Ulmer HU, Frenzel H, Komitowski D (1996) Allelic imbalance on chromosome 13q: evidence for the involvement of BRCA2 and RB1 in sporadic breast cancer. Cancer Res 56:1988-1990

35. Eiriksdottir G, Johannesdottir G, Ingvarsson S, Björnsdottir IB, Jonasson JG, Egilsson V, Barkardottir RB (1998) Mapping loss of heterozygosity at chromosome 13q: loss at 13q12-q13 associates with breast tumour progression and poor prognosis of patients. Eur J Cancer 34:2076-2081

36. Tsuda H, Hirohashi S (1995) Identification of multiple breast cancers of multicentric origin by histological observations and distribution of allele loss on chromosome 16q. Cancer Res 55:3395-3398

37. Cleton-Jansen AM, Moerland EW, Kuipers-Dijkshoorn NJ, Callen DF, Sutherland GR, Hansen B, Devilee P, Cornelisse CJ (1994) At least two different regions are involved in allelic imbalance on chromosome arm 16q in breast cancer. Genes Chromosomes Cancer 9:101-107

38. Skirnisdottir S, Eiriksdottir G, Baldursson T, Barkardottir RB, Egilsson V, Ingvarsson S (1995) High frequency of allelic imbalance at chromosome region 16q22-q23 in human breast cancer: correlation with high $\mathrm{PgR}$ and low S-phase. Int J Cancer 64:112-116

39. Dorion-Bonnet F, Mautalen S, Hostein I, Longy M (1995) Allelic imbalance study of $16 \mathrm{q}$ in human primary breast carcinomas using microsatellite markers. Genes Chromosomes Cancer 14:171-181

40. Cornelis RS, van Vliet M, Vos CB, Cleton-Jansen AM, van de Vijver MJ, Peterse JL, Khan PM, Borresen AL, Cornelisse CJ, Devilee P (1994) Evidence for a gene on 17p13.3, distal to TP53, as a target for allele loss in breast tumors without p53 mutations. Cancer Res 54:4200-4206

41. Isomura M, Tanigami A, Saito H, Harada Y, Katagiri T, Inazawa J (1994) Ledbetter DH. Nakamura Y. Detailed analysis of loss of heterozygosity on chromosome band 17p13 in breast carcinoma on the basis of a high-resolution physical map with 29 markers. Genes Chromosomes Cancer 9: 173-179

42. Stack M, Jones D, White G, Liscia DS, Venesio T, Casey G, Crichton D, Varley J, Mitchell E, Heighway J et al (1995) Detailed mapping and loss of heterozygosity analysis suggests a suppressor locus involved in sporadic breast cancer within a distal region of chromosome band 17p13.3. Hum Mol Genet 4:2047-2055

43. Cornelis RS, Devilee P, van Vliet M, Kuipers-Dijkshoorn N, Kersenmaeker A, Bardoel A, Khan PM, Cornelisse CJ (1993) Allele loss patterns on chromosome $17 \mathrm{q}$ in 109 breast carcinomas indicate at least two distinct target regions. Oncogene 8:781-785

44. Phelan CM, Borg A, Cuny M, Crichton DN, Baldursson T, Andersen TI, Caligo MA, Lidereau R, Lindblom A, Seitz S, Kelsell D, Hamann U, Rio P, Thorlacius S, Papp J, Olah E, Ponder B, Bignon YJ, Scherneck S, Barkardottir R, Borresen-Dale AL, Eyfjord J, Theillet C, Thompson AM, Larsson C (1998) Consortium study on 1280 breast carcinomas: allelic loss on chromosome 17 targets subregions associated with family history and clinical parameters. Cancer Res 58:1004-1012

45. Thompson AM, Morris RG, Wallace M, Wyllie AH, Steel CM, Carter DC (1993) Allele loss from 5q21 (APC/MCC) 
and 18q21 (DCC) and DCC mRNA expression in breast cancer. Br J Cancer 68:64-68

46. Huang TH, Yeh PL, Martin MB, Straub RE, Gilliam TC, Caldwell CW, Skibba JL (1998) Genetic alterations of microsatellites on chromosome 18 in human breast carcinoma. Diagn Mol Pathol 4:66-72

47. Schenk M, Leib-Mosch C, Schenck IU, Jaenicke M, Indraccolo S, Saeger HD, Dallenbach-Hellweg G, Hehlmann R (1996) Lower frequency of allele loss on chromosome $18 q$ in human breast cancer than in colorectal tumors. J Mol Med 74:155-159

48. Huiping C, Eiriksdottir G, Sigurdsson A, Sigurgeirsdottir JR, Barkardottir RB, Egilsson V, Ingvarsson S (1998) High frequency of $\mathrm{LOH}$ at chromosome $18 \mathrm{q}$ in human breast cancer: association with high S-phase fraction and low progesterone receptor content. Anticancer Res 18:1031-1036

49. Kallioniemi A, Kallioniemi OP, Piper J, Tanner M, Stokke T, Chen L, Smith HS, Pinkel D, Gray JW, Waldman FM (1994) Detection and mapping of amplified DNA sequences in breast cancer by comparative genomic hybridization. Proc Natl Acad Sci USA 91:2156-2160

50. Muleris M, Almeida A, Gerbault-Seureau M, Malfoy B, Dutrillaux B (1994) Detection of DNA amplification in 17 primary breast carcinomas with homogeneously staining regions by a modified comparative genomic hybridization technique. Genes Chromosomes Cancer 10:160-170

51. Courjal F, Cuny M, Rodriguez C, Louason G, Speiser P, Katsaros D, Tanner MM, Zeillinger R, Theillet C (1996) DNA amplifications at 20q13 and MDM2 define distinct subsets of evolved breast and ovarian tumours. Br J Cancer 74:

1984-1989

52. Tanner MM, Tirkkonen M, Kallioniemi A, Isola J, Kuukasjarvi T, Collins C, Kowbel D, Guan XY, Trent J, Gray JW, Meltzer P, Kallioniemi OP (1996) Independent amplification and frequent co-amplification of three nonsyntenic regions on the long arm of chromosome 20 in human breast cancer. Cancer Res 56:3441-3445

53. Iida A, Kurose K, Isobe R, Akiyama F, Sakamoto G, Yoshimoto M, Kasumi F, Nakamura Y, Emi M (1998) Mapping of a new target region of allelic loss to a 2-cM interval at 22q13.1 in primary breast cancer. Genes Chromosomes Cancer 21:108-112

54. Loupart ML, Adams S, Armour JA, Walker R, Brammar W, Varley J (1995) Loss of heterozygosity on the X chromosome in human breast cancer. Genes Chromosomes Cancer 13: 229-238

55. Theillet C, Adnane J, Szepetowski P, Simon MP, Jeanteur P, Birnbaum D, Gaudray P (1990) BCL-1 participates in the $11 \mathrm{q} 13$ amplification found in breast cancer. Oncogene 5:147-149

56. Bieche I, Tomasetto C, Regnier CH, Moog-Lutz C, Rio MC, Lidereau R (1996) Two distinct amplified regions at 17q11q21 involved in human primary breast cancer. Cancer Res 56:3886-3890

57. Pauletti G, Godolphin W, Press MF, Slamon DJ (1996) Detection and quantitation of HER-2/neu gene amplification in human breast cancer archival material using fluorescence in situ hybridization. Oncogene 13:63-72

58. Gusterson BA, Machin LG, Gullick WJ, Gibbs NM, Powles TJ, Elliott C, Ashley S, Monaghan P, Harrison S (1988) c-erbB-2 expression in benign and malignant breast disease. Br J Cancer 58:453-457

59. Kallioniemi OP, Holli K, Visakorpi T, Koivula T, Helin HH, Isola JJ (1991) Association of c-erbB-2 protein over-expression with high rate of cell proliferation, increased risk of visceral metastasis and poor long-term survival in breast cancer. Int J Cancer 49:650-655

60. McIntosh GG, Anderson JJ, Milton I, Steward M, Parr AH,
Thomas MD, Henry JA, Angus B, Lennard TW, Horne CH (1995) Determination of the prognostic value of cyclin D1 overexpression in breast cancer. Oncogene 11:885-891

61. Press MF, Pike MC, Chazin VR, Hung G, Udove JA, Markowicz M, Danyluk J, Godolphin W, Sliwkowski M, Akita $\mathrm{R}$ et al (1993) Her-2/neu expression in node-negative breast cancer: direct tissue quantitation by computerized image analysis and association of overexpression with increased risk of recurrent disease. Cancer Res 53:4960-4970

62. Baselga J, Tripathy D, Mendelsohn J, Baughman S, Benz CC, Dantis L, Sklarin NT, Seidman AD, Hudis CA, Moore J, Rosen PP, Twaddell T, Henderson IC, Norton L (1996) Phase II study of weekly intravenous recombinant humanized anti-p185HER2 monoclonal antibody in patients with HER2/neu-overexpressing metastatic breast cancer. J Clin Oncol 14:737-744

63. Hartmann A, Blaszyk H, Kovach JS, Sommer SS (1997) The molecular epidemiology of p53 gene mutations in human breast cancer. TIG 13:27-33

64. Kastan MB, Zhan Q, el-Deiry WS, Carrier F, Jacks T, Walsh WV, Plunkett BS (1992) Vogelstein B. Fornace AJ Jr. A mammalian cell cycle checkpoint pathway utilizing p53 and GADD45 is defective in ataxia-telangiectasia. Cell 71:587-597

65. Kuerbitz SJ, Plunkett BS, Walsh WV, Kastan MB (1992) Wild-type p53 is a cell cycle checkpoint determinant following irradiation. Proc Natl Acad Sci USA 89:7491-7495

66. Yin Y, Tainsky MA, Bischoff FZ, Strong LC, Wahl GM (1992) Wild-type p53 restores cell cycle control and inhibits gene amplification in cells with mutant p53 alleles. Cell 70:937-948

67. el-Deiry WS, Harper JW, O'Connor PM, Velculescu VE, Canman CE, Jackman J, Pietenpol JA, Burrell M, Hill DE, Wang Y et al (1994) WAF1 / CIP1 is induced in p53-mediated G1 arrest and apoptosis. Cancer Res 54:1169-1174

68. Miyashita T, Reed JC (1995) Tumor suppressor p53 is a direct transcriptional activator of the human bax gene. Cell 80:293-299

69. Malkin D, Li FP, Strong LC, Fraumeni JF Jr, Nelson CE, Kim DH, Kassel J, Gryka MA, Bischoff FZ, Tainsky MA et al (1990) Germ line p53 mutations in a familial syndrome of breast cancer, sarcomas, and other neoplasms. Science 250: 1233-1238

70. Berx G, Cleton-Jansen AM, Nollet F, de Leeuw WJ, van de Vijver M, Cornelisse C, van Roy F (1995) E-cadherin is a tumour/invasion suppressor gene mutated in human lobular breast cancers. EMBO J 14:6107-6115

71. Berx G, Cleton-Jansen AM, Strumane K, de Leeuw WJ, Nollet F, van Roy F, Cornelisse C (1996) E-cadherin is inactivated in a majority of invasive human lobular breast cancers by truncation mutations throughout its extracellular domain. Oncogene 13:1919-1925

72. Vos CB, Cleton-Jansen AM, Berx G, de Leeuw WJ, ter Haar NT, van Roy F, Cornelisse CJ, Peterse JL, van de Vijver MJ (1997) E-cadherin inactivation in lobular carcinoma in situ of the breast: an early event in tumorigenesis. Br J Cancer 76:1131-1133

73. Oka H, Shiozaki H, Kobayashi K, Inoue M, Tahara H, Kobayashi T, Takatsuka Y, Matsuyoshi N, Hirano S, Takeichi $\mathrm{M}$ et al (1993) Expression of E-cadherin cell adhesion molecules in human breast cancer tissues and its relationship to metastasis. Cancer Res 53:1696-1701

74. Gamallo C, Palacios J, Benito N (1996) Expression of Ecadherin in 230 infiltrating ductal breast carcinomas-relationship to clinicopathologic features. Int $\mathrm{J}$ Oncol 9:1207-1212

75. Knudson AG (1971) Mutation and cancer: statistical study of retinoblastoma. Proc Natl Acad Sci USA 68:820-823

76. Guilford P, Hopkins J, Harraway J, McLeod M, McLeod N, Harawira P, Taite H, Scoular R, Miller A, Reeve AE (1998) 
E-cadherin germline mutations in familial gastric cancer. Nature 392:402-405

77. Murphy LC, Dotzlaw H, Leygue E, Douglas D, Coutts A, Watson PH (1997) Estrogen receptor variants and mutations. J Ster Biochem Mol Biol 62:363-372

78. Dowsett M, Daffada A, Chan CM, Johnston SR (1997) Oestrogen receptor mutants and variants in breast cancer. Eur J Cancer 33:1177-1183

79. Pfeffer U, Fecarotta E, Vidali G (1995) Coexpression of multiple estrogen receptor variant messenger RNAs in normal and neoplastic breast tissues and in MCF-7 cells. Cancer Res 55:2158-2165

80. Leygue ER, Huang A, Murphy LC (1996) Estrogen receptor variants in normal human mammary tissue. J Natl Cancer Inst 88:284-290

81. Wang M, Dotzlaw H, Fuqua SA, Murphy LC (1997) A point mutation in the human estrogen receptor gene is associated with the expression of an abnormal estrogen receptor mRNA containing a 69 novel nucleotide insertion. Breast Cancer Res Treat 44:145-151

82. Zhang QX, Borg A, Wolf DM, Oesterreich S, Fuqua SA (1997) An estrogen receptor mutant with strong hormoneindependent activity from a metastatic breast cancer. Cancer Res 57:1244-1249

83. England GM, Bilimoria MM, Chen ZH, Assikis VJ, Muenzner HD, Jordan VC (1998) Characterization of a point mutation in the hormone binding domain of the estrogen receptor from an estrogen independent breast tumor. Int J Oncol 12:981-986

84. Zelada-Hedman M, Borresen-Dale AL, Lindblom A (1997) Screening of 229 family cancer patients for a germline estrogen receptor gene (ESR) base mutation. Hum Mut 9:289

85. Rhei E, Kang L, Bogomolniy F, Federici MG, Borgen PI, Boyd J (1997) Mutation analysis of the putative tumor suppressor gene PTEN/MMAC1 in primary breast carcinomas. Cancer Res 57:3657-3659

86. Ueda K, Nishijima M, Inui H, Watatani M, Yayoi E, Okamura J, Yasutomi M, Nakamura Y, Miyoshi Y (1998) Infrequent mutations in the PTEN/MMAC1 gene amount primary breast cancer. Jap J Cancer Res 89:17-21

87. Lynch ED, Ostermeyer EA, Lee MK, Arena JF, Ji HL, Dann J, Swisshelm K, Suchard D, Macleod PM, Kvinnsland S, Gjertsen BT, Heimdal K, Lubs H, Moller P, King MC (1997) Inherited mutations in PTEN that are associated with breast cancer, Cowden-disease, and juvenile polyposis. Am J Hum Genet 61:1254-1260

88. Miki Y, Swensen J, Shattuck-Eidens D, Futreal AP, Harshman K, Tavtigian S, Liu Q, Cochran C, Bennett ML, Ding W, Bell R, Rosenthal J, Hussey C, Tran T, McClure M, Frye C, Hattier T, Phelps R, Haugen-Strano A, Katcher H, Yakumo K, Gholami Z, Shaffer D, Stone S, Bayer S, Wray C, Bogden R, Dayananth P, Ward J, Tonin P, Narod S, Bristow PK, Norris FH, Helvering L, Morrison P, Rosteck P, Lai M, Barrett JK, Lewis C, Neuhausen S, Cannon-Albright L, Goldgar D, Wiseman R, Kamb S, Skolnick MH (1994) A strong candidate for the breast and ovarian cancer susceptibility gene BRCA1. Science 266:66-71

89. Wooster R, Bignell G, Lancaster J, Swift S, Seal S, Mangion J, Collins N, Gregory S, Gumbs C, Micklem G, Barfoot R, Hamoudi R, Patel S, Rice C, Biggs P, Hashim Y, Smith A, Connor F, Arason A, Gudmundsson J, Ficenec D, Kelsell D, Ford D, Tonin P, Bishop DT, Spurr NK, Ponder BAJ, Eeles R, Peto J, Devilee P, Cornelisse C, Lynch H, Narod S, Lenoir G, Egilsson V, Barkardottir RB, Easton DF, Bentley DR, Futreal PA, Ashworth A, Stratton MR (1995) Identification of the breast cancer susceptibility gene BRCA2. Nature 378:789-792

90. Miki Y, Katagiri T, Kasumi F, Yoshimoto T, Nakamura Y
(1996) Mutation analysis in the BRCA2 gene in primary breast cancers. Nat Genet 13:245-247

91. Teng DH, Bogden R, Mitchell J, Baumgard M, Bell R, Berry S, Davis T, Ha PC, Kehrer R, Jammulapati S, Chen Q, Offit K, Skolnick MH, Tavtigian SV, Jhanwar S, Swedlund B, Wong AK, Kamb A (1996) Low incidence of BRCA2 mutations in breast carcinoma and other cancers. Nat Genet 13:241-244

92. Bergthorsson JT, Eiriksdottir G, Barkardottir RB, Egilsson V, Arason A, Ingvarsson S (1995) Linkage analysis and allelic imbalance in human breast cancer kindreds using microsatellite markers from the short arm of chromosome 3 . Hum Genet 96:437-443

93. Tirkkonen M, Johannsson O, Agnarsson BA, Olsson H, Ingvarsson S, Karhu R, Tanner M, Isola J, Barkardottir RB, Borg A, Kallioniemi OP (1997) Distinct somatic genetic changes associated with tumor progression in carriers of BRCA1 and BRCA2 germ-line mutations. Cancer Res $57: 1222-1227$

94. Bergthorsson JT, Johannsdottir J, Jonasdottir A, Eriksdottir $\mathrm{G}$, Egilsson $\mathrm{V}$, Ingvarsson $\mathrm{S}$, Barkardottir RB, Arason A (1998) Chromosome imbalance at the 3p14 region in human breast tumors; High frequency in patients with inherited predisposition due to BRCA2. Eur J Cancer 34:142-147

95. Ingvarsson $S$, Geirsdottir EK, Johannesdottir G, Sigbjörnsdóttir BI, Eiriksdottir G, Ragnarsson G, Agnarsson BA, Gudmundsson J, Jonasson JG, Sigurdsson A, Egilsson V, Barkardottir RB (1998) High incidence of loss of heterozygosity in breast tumors from carriers of the 999del5 BRCA2 mutation. Cancer Res 58:4421-4425

96. Smith SA, Easton DF, Evans DG, Ponder BA (1992) Allele losses in the region $17 q 12-21$ in familial breast and ovarian cancer involve the wild-type chromosome. Nat Genet 2: 128-131

97. Gudmundsson J, Johannesdottir G, Bergthorsson JT, Arason A, Ingvarsson S, Egilsson V, Barkardottir RB (1995) Different tumor types from BRCA2 carriers show wild-type chromosome deletions on 13q12-q13. Cancer Res 55:4830-4832

98. Collins N, McManus R, Wooster R, Mangion J, Seal S, Lakhani SR, Ormiston W, Daly PA, Ford D, Easton DF, Stratton MR (1995) Consistent loss of the wild type allele in breast cancers from a family linked to the BRCA2 gene on chromosome 13q12-13. Oncogene 10:1673-1675

99. Ahmadian M, Wistuba II, Fong KM, Behrens C, Kodagoda DR, Saboorian MH, Shay J, Tomlinson GE, Blum J, Minna JD, Gazdar AF (1997) Analysis of the FHIT gene and FRA3B region in sporadic breast cancer, preneoplastic lesions, and familial breast cancer probands. Cancer Res 57:3664-3668

100. Hayashi S, Tanimoto K, Hajironakanishi K, Tsuchiya E, Kurosumi M, Higashi Y, Imai K, Suga K, Nakachi K (1997) Abnormal FHIT transcripts in human breast carcinomas-a clinicopathological and epidemiological analysis of 61 Japanese cases. Cancer Res 57:1981-1985

101. Negrini M, Monaco C, Vorechovsky I, Ohta M, Druck T, Baffa R, Huebner K, Croce CM (1996) The FHIT gene at 3 p14.2 is abnormal in breast carcinomas. Cancer Res 56:3173-3179

102. Siprashvili Z, Sozzi G, Barnes LD, Mccue P, Robinson AK, Eryomin V, Sard L, Tagliabue E, Greco A, Fusetti L, Schwartz G, Pierotti MA, Croce CM, Huebner K (1997) Replacement of FHIT in cancer cells suppresses tumorigenicity. Proc Natl Acad Sci USA 94:13771-13776

103. Ohta M, Inoue H, Cotticelli MG, Kastury K, Baffa R, Palazzo J, Siprashvili Z, Mori M, McCue P, Druck T et al (1996) The FHIT gene, spanning the chromosome 3p14.2 fragile site and renal carcinoma-associated $\mathrm{t}(3 ; 8)$ breakpoint, is abnormal in digestive tract cancers. Cell 84:587-597

104. Crook T, Crossland S, Crompton MR, Osin P, Gusterson BA 
(1997) P53 mutations in BRCA1-associated familial breast cancer. Lancet 350:638-639

105. Eiriksdottir G, Barkardottir RB, Agnarsson BA, Johannesdottir G, Olafsdottir K, Egilsson V, Ingvarsson S (1998) High incidence of loss of heterozygosity at chromosome 17p13 in breast tumours from BRCA2 mutation carriers. Oncogene $16: 21-26$

106. Ludwig T, Chapman DL, Papaioannou VE, Efstratiadis A (1997) Targeted mutations of breast cancer susceptibility gene homologs in mice-lethal phenotypes of BRCA1, BRCA2, BRCA1/BRCA2, BRCA1/P53, and BRCA2/P53 nullizygous embryos. Genes Dev 11:1226-1241

107. Connor F, Bertwistle D, Mee PJ, Ross GM, Swift S, Grigorieva E, Tybulewicz VLJ, Ashworth A (1997) Tumorigenesis and a DNA repair defect in mice with a truncating Brca2 mutation. Nature Genet 17:423-430

108. Gretarsdottir S, Thorlacius S, Valgardsdottir R, Gudlaugsdottir S, Sigurdsson S, Steinarsdottir M, Jonasson JG, Anamthawatjonsson K, Eyfjord JE (1998) BRCA2 and P53 mutations in primary breast cancer in relation to genetic instability. Cancer Res 58:859-862

109. Scully R, Chen J, Plug A, Xiao Y, Weaver D, Feunteun J, Ashley T, Livingston DM (1997) Association of BRCA1 with Rad51 in mitotic and meiotic cells. Cell 88:265-275

110. Sharan SK, Morimatsu M, Albrecht U, Lim DS, Regel E, Dinh C, Sands A, Eichele G, Hasty P, Bradley A (1997) Embryonic lethality and radiation hypersensitivity mediated by rad51 in mice lacking brca2. Nature 386:804-810

111. Patel KJ, Yu VPCC, Lee HS, Corcoran A, Thistlethwaite FC, Evans MJ, Colledge WH, Friedman LS, Ponder BAJ, Venkitaraman AR (1998) Involvement of BRCA2 in DNA repair. Mol Cell 1:347-357

112. Agnarsson BA, Jonasson JG, Björnsdottir IB, Barkardottir RB, Egilsson V, Sigurdsson H (1998) Inherited BRCA2 mutation associated with high grade breast cancer. Breast Cancer Res Treat 47:121-127

113. Munn KE, Walker RA, Varley JM (1995) Frequent alterations of chromosome 1 in ductal carcinoma in situ of the breast. Oncogene 10:1653-1657

114. Radford DM, Fair KL, Phillips NJ, Ritter JH, Steinbrueck T, Holt MS, Donis-Keller H (1995) Allelotyping of ductal carcinoma in situ of the breast: deletion of loci on $8 p, 13 q, 16 q$, $17 p$ and $17 q$. Cancer Res 55:3399-33405

115. Zhuang Z, Merino MJ, Chuaqui R, Liotta LA, Emmert-Buck MR (1995) Identical allelic loss on chromosome 11q13 in microdissected in situ and invasive human breast cancer. Cancer Res 55:467-471

116. Munn KE, Walker RA, Menasce L, Varley JM (1996) Mutation of the TP53 gene and allelic imbalance at chromosome 17 p13 in ductal carcinoma in situ. Br J Cancer 74:1578-1585

117. Munn KE, Walker RA, Menasce L, Varley JM (1996) Allelic imbalance in the region of the BRCA1 gene in ductal carcinoma in situ of the breast. Br J Cancer 73:636-639

118. O'Connell P, Pekkel V, Fuqua S, Osborne CK, Allred DC (1994) Molecular genetic studies of early breast cancer evolution. Breast Cancer Res Treat 32:5-12

119. Lizard-Nacol S, Lidereau R, Collin F, Arnal M, Hahnel L, Roignot P, Cuisenier J, Guerrin J (1995) Benign breast disease: absence of genetic alterations at several loci implicated in breast cancer malignancy. Cancer Res 55: 4416-4419

120. Fantl V, Richards MA, Smith R, Lammie GA, Johnstone G, Allen D, Gregory W, Peters G, Dickson C, Barnes DM (1990) Gene amplification on chromosome band 11 q13 and oestrogen receptor status in breast cancer. Eur J Cancer 26:423-429

121. Ramachandra S, Machin L, Ashley S, Monaghan P, Gusterson BA (1990) Immunohistochemical distribution of c-erbB-2 in in situ breast carcinoma-a detailed morphological analysis. J Pathol 161:7-14

122. Barnes DM, Bartkova J, Camplejohn RS, Gullick WJ, Smith PJ, Millis RR (1992) Overexpression of the c-erbB-2 oncoprotein: why does this occur more frequently in ductal carcinoma in situ than in invasive mammary carcinoma and is this of prognostic significance? Eur J Cancer 28:644-648

123. O'Connell P, Pekkel V, Fuqua SAW, Osborne CK, Clark GM, Allred DC (1998) Analysis of loss of heterozygosity in 399 premalignant breast lesions at 15 genetic loci. J Natl Cancer Inst 90:697-703

124. Lakhani SR, Collins N, Stratton MR, Sloane JP (1995) Atypical ductal hyperplasia of the breast: clonal proliferation with loss of heterozygosity on chromosomes $16 \mathrm{q}$ and $17 \mathrm{p}$. J Clin Pathol 48:611-615

125. Lakhani SR, Slack DN, Hamoudi RA, Collins N, Stratton MR, Sloane JP (1996) Detection of allelic imbalance indicates that a proportion of mammary hyperplasia of usual type are clonal, neoplastic proliferations. Lab Invest 74: 129-135

126. Deng G, Lu Y, Zlotnikov G, Thor AD, Smith HS (1996) Loss of heterozygosity in normal tissue adjacent to breast carcinomas. Science 274:2057-2059

127. Radford DM, Phillips NJ, Fair KL, Ritter JH, Holt M, DonisKeller H (1995) Allelic loss and the progression of breast cancer. Cancer Res 55:5180-5183

128. Wick W, Petersen I, Schmutzler RK, Wolfarth B, Lenartz D, Bierhoff E, Hummerich J, Muller DJ, Stangl AP, Schramm J, Wiestler OD, von Deimling A (1996) Evidence for a novel tumor suppressor gene on chromosome 15 associated with progression to a metastatic stage in breast cancer. Oncogene 12:973-978

129. Parson R, Li GM, Longlay MJ, Fang WH, Papadopoulos N, Jen J, De La Chapelle A, Kinzler KW, Vogelstein B, Modrich $P$ (1993) Hypermutability and mismatch repair deficiency in RER $^{+}$tumor cells. Cell 75:1227-1236

130. Thibodeau SN, Bren G, Schaid D (1993) Microsatellite instability in cancer of the proximal colon. Science 260:816-819

131. Ionov Y, Peinado MA, Malkhosyan S, Shibata D, Perucho M (1993) Ubiquitous somatic mutations in simple repeat sequences reveal a new mechanism for colorectal carcinogenesis. Nature 363:558-561

132. Peltomaki P, Lothe RA, Aaltonen LA, Pylkkanen L, Nystromlahti M, Seruca R, David L, Holm R, Ryberg D, Haugen A, Brogger A, Borresen AL, De La Chapelle A (1993) Microsatellite instability is associated with tumors that characterize the heredity non-polyposis colorectal carcinoma syndrome. Cancer Res 53:5853-5855

133. Glebov OK, Mckenzie KE, White CA, Sukumar S (1994) Frequent p53 gene mutations and novel alleles in familial breast cancer. Cancer Res 54:3703-3709

134. Rhyu MG, Park WS, Meltzer SJ (1994) Microsatellite instability occurs frequently in human gastric carcinoma. Oncogene 9:29-32

135. Shridhar V, Siegfried J, Hunt J, Alonso M, Smith DI (1994) Genetic instability of microsatellite sequences in many nonsmall-cell lung carcinomas. Cancer Res 54:2084-2087

136. Wooster R, Cleton-Jansen AM, Collins N, Mangion J, Cornelis RS, Cooper CS, Gusterson BA, Ponder BAJ, Vondeimling A, Wiestler OD, Cornelisse CJ, Devilee P, Stratton MR (1994) Instability of short tandem repeats (microsatellites) in human cancers. Nat Genet 6:152-156

137. Mecklin JP, Jarvinen HJ (1991) Tumor spectrum in cancer family syndrome (heredity non-polyposis colorectal cancer). Cancer 68:1109-1112

138. Aldaz CM, Chen T, Sahin A, Cunningham J, Bondy M (1995) Comparative allelotype of in situ and invasive human 
breast cancer: high frequency of microsatellite instability in lobular breast carcinomas. Cancer Res 55:3976-3981

139. Karnik P, Plummer S, Casey G, Myles J, Tubbs R, Growe J, Williams BR (1995) Microsatellite instability at a single locus (D11S988) on chromosome 11p15.5 as a late event in mammary tumorigenesis. Hum Mol Genet 4:1889-1894

140. Jonsson M, Johannsson O, Borg A (1995) Infrequent occurrence of microsatellite instability in sporadic and familial breast cancer. Eur J Cancer 31A:2330-2334

141. Toyama T, Iwase H, Yamashita H, Iwata H, Yamashita T, Ito K, Hara Y, Suchi M, Kato T, Nakamura T, Kobayashi S (1996) Microsatellite instability in sporadic human breast cancers. Int J Cancer 68:447-451

142. Huiping C, Johannsdottir JT, Arason A, Olafsdottir GH, Eiriksdottir G, Egilsson V, Ingvarsson S (1999) Replication error in human breast cancer: comparison with clinical variables and family history of cancer. Oncol Rep 6:117-122

143. Bergthorsson JT, Egilsson V, Gudmundsson J, Arason A, Ingvarsson S (1995) Identification of a breast tumor with microsatellite instability in a carrier of the hereditary nonpolyposis colon cancer trait. Clin Genet 47:305-310

144. Borg A, Tandon AK, Sigurdsson H, Clark GM, Ferno M, Fuqua SA, Killander D, McGuire WL (1990) HER-2/neu amplification predicts poor survival in node-positive breast cancer. Cancer Res 50:4332-4337
145. Paterson MC, Dietrich KD, Danyluk J, Paterson AH, Lees AW, Jamil N, Hanson J, Jenkins H, Krause BE, McBlain WA et al (1991) Correlation between c-erbB-2 amplification and risk of recurrent disease in node-negative breast cancer. Cancer Res 51:556-567

146. Thorlacius S, Borresen AL, Eyfjord JE (1993) Somatic p53 mutations in human breast carcinomas in an Icelandic population: a prognostic factor. Cancer Res 53:1637-1641

147. Falette N, Paperin MP, Treilleux I, Gratadour AC, Peloux N, Mignotte H, Tooke N, Lofman E, Inganas M, Bremond A, Ozturk M, Puisieux A (1998) Prognostic value of p53 gene mutations in a large series of node-negative breast cancer patients. Cancer Res 58:1451-1455

148. Bieche I, Nogues C, Rivoilan S, Khodja A, Latil A, Lidereau R (1997) Prognostic value of loss of heterozygosity at BRCA2 in human breast carcinoma. Br J Cancer 76:1416-1418

149. Lipponen P, Saarelainen E, Aaltomaa S, Syrjanen K (1994) Expression of E-cadherin (E-CD) is related to other prognostic factors and survival in breast cancer. J Pathol 174:101-109

150. Charpin C, Garcia S, Bonnier P, Martini F, Andrac L, Choux R, Lavaut MN, Allasia C (1998) Reduced E-cadherin immunohistochemical expression in node-negative breast carcinomas correlates with 10-year survival. Am J Clin Pathol 109:431-438 